\title{
FREQUENCY OF VERULENCE AND VIRULENCE FORMULA OF WHEAT STEM RUST RACES IDENTIFIED IN EGYPT DURING 2008/09 - 2009/010. \\ Faizallah, E.A. ${ }^{1}$; W. A. Youseef ${ }^{2}$ and O. A. El Sayed ${ }^{2}$ \\ 1- Plant Pathology Dept., Fac. of Agriculture, Mansoura Univ., Egypt \\ 2- Institute of Plant Pathology, ARC., Giza, Egypt .
}

\begin{abstract}
Wheat stem rust is one of the major diseases on wheat in Egypt which appears annually in virulence of different frequencies. In this investigation, stem rust samples were collected from different locations of lower Egypt during two seasons (2008/09 2009/010). Three single pustules method of isolation was followed for each sample. Rust data were recorded as infection types, and virulence frequencies were determined against $35 \mathrm{Sr}$ genes, in monogenic lines and some Egyptian genotypes. Virulence frequencies were very high against $\mathrm{Sr} 21+9 g, \mathrm{Sr} 7 \mathrm{a}, \mathrm{Sr} 16, \mathrm{Sr} 9 e, \mathrm{Sr} 6$ and $\mathrm{Sr} 17$, while the lowest frequencies were recorded against $\mathrm{Sr} 31, \mathrm{Sr} 29$ and $\mathrm{Sr} 30$. The physiologic races were identified according to their reaction on the $20 \mathrm{Srs}$ were recorded for each race. Thirteen and two physiologic races of Puccinia garminis were dantefiand. Race group TT- was the most frequent $(16.16 \%)$, race group TS(11.76\%) ,race group KT- and TK- ( $5.88 \%$ ) followed by race group BB-, DH, PR, and SR $(2.94 \%)$. The least ones in the regard were races of group $\mathrm{BC}, \mathrm{BH}<\mathrm{BK}, \mathrm{DG}, \mathrm{DF}$ and DT $(0.98 \%)$ keywords: Wheat stem rust race and virulence .
\end{abstract}

\section{INTRODUCTION}

Stem rust (Puccinia garminis) is a common disease on wheat in all areas in Egypt. Nevertheless, disease infection with stem rust usually occurs only at the late growth stages starting from flowering stage. No disease infection was recorded on seedling other under field conditions. Therefore, breeding for adult plant resistance is the most important method to control such disease under Egyptian conditions.

Stem rust can be considered as acamman disease because it appears every season. It appeared in epidemic cases in 1947 and 1968 (Gomma 1968 ) and. More over, all wheat genotypes produced in Egypt are susceptible in Therefore, to protect the local genotypes from infection genes for resistance should be incorporated into the high yielding genotypes.

Disease resistance is controlled by major or minor genes or both together, however complementary effect between major genes may enhance the response of a variety and give higher levels of resistance ( Simons et al., 1978 ).

Many of the major genes are effective through the whole life of the plant, whereas a few are only effective at the adult stage. Resistance during later periods of plant growth is called adult plant resistance as defined by (ElDaoudi et. al., 1990) as the resistance that is only effective in the advanced growth stages of the plant . 
Faizallah, E.A. et al.

Expression of resistance depends on the host-parasite interaction, environmental conditions, plant growth stage and the interaction between resistance genes in the wheat genome (Bolate, N.and A. P.Roelfs,(1991).

Therefore, the objective of the presents investigation is to study stemrust virulence against single genes for resistance and also against the local genotypes, to serve the national breeding program for resistance.

\section{MATERIALS AND METHODS}

Naturaly infected leaf specimens were collected from different wheat growing areas in Egypt during 2008/09-2009/010. Samples were obtained from the commercial fields as well as from wheat stem rust trap nursery, from lines carrying known genes for stem rust resistance ( $\mathrm{Sr} s$ ).

Each specimen was transferred onto 8-9 days - old seedlings of the highly susceptible cv. Giza 160 under greenhouse conditions.

Three single pustules were tested per each sample, and each culture was increased on seedlings cv. Giza 160 to generate sufficient inocula (spores) to inoculate the set of differentials, following the method of Stakman et al., (1962).

Infection types were recorded according to scale of 0-4 grades (Stakman et al., (1962).) as shown in (Table, 1). Wheat seedlings of eight days old were sprayed with tap water and the leaves were gently rubbed between moistened fingers and again sprayed with water by an atomizer in the inoculation chambers. Inoculation was carried out by shaking and brushing rust spores over the plant leaves and sprayed gently again with water in order to induce an initial thin film of water on the plant leaves. while the temperature was $20-25{ }^{\circ} \mathrm{C}$ and relative humidity of $90 \%$ was supplied. (Roelfs,A.P. and J.W.Mertens ( 1988). And Roelfs,A.P.;D.L.long and J.J.Roberts(1993) Frequency of virulence was determined against two sets of genotypes. The first set included local wheat genotypes, whereas the second set included 36 monogenic lines carrying adult-plant resistance genes. The frequency of virulence was estimated as the percentage of virulent isolates divided by the total number of isolates for each genotype.

Virulence $(\%)=\frac{\text { susceptible response }}{\text { Total number of isolates }} \times 100$

According to the method adopted by Green (1965). 
Table (1): Pgt-code for the 12 Pgt differential hosts for Puccinia graminis $\mathrm{f}$. sp. tritici in ordered subsets of four groups.

\begin{tabular}{|l|l|c|c|c|c|}
\hline \multirow{3}{*}{} & \multicolumn{3}{|c|}{ Subset $^{\text {a }}$} & \multicolumn{3}{|c|}{ Infection type produced on host lines with Sr } \\
\cline { 2 - 6 } & 1 & 5 & 21 & $9 \mathrm{e}$ & $7 \mathrm{~b}$ \\
\cline { 2 - 6 } & 2 & 11 & 6 & $8 \mathrm{a}$ & $9 \mathrm{~g}$ \\
\cline { 2 - 6 } & 3 & 36 & $9 \mathrm{~b}$ & 30 & 17 \\
\cline { 2 - 6 } & 4 & $9 \mathrm{a}$ & $9 \mathrm{~d}$ & 10 & Tmp \\
\cline { 2 - 6 } & 5 & $7 \mathrm{a}$ & $8 \mathrm{~b}$ & 13 & 15 \\
\hline $\mathbf{B}$ & & Low & Low & Low & Low \\
\hline $\mathbf{C}$ & & Low & Low & Low & High \\
\hline $\mathbf{D}$ & & Low & Low & High & Low \\
\hline $\mathbf{F}$ & & Low & Low & High & High \\
\hline $\mathbf{G}$ & & Low & High & Low & Low \\
\hline $\mathbf{H}$ & & Low & High & Low & High \\
\hline $\mathbf{J}$ & & Low & High & High & Low \\
\hline $\mathbf{K}$ & & Low & High & High & High \\
\hline $\mathbf{L}$ & & High & Low & Low & Low \\
\hline $\mathbf{M}$ & & High & Low & Low & High \\
\hline $\mathbf{N}$ & & High & Low & High & Low \\
\hline $\mathbf{P}$ & & High & Low & High & High \\
\hline $\mathbf{Q}$ & & High & High & Low & Low \\
\hline $\mathbf{R}$ & & High & High & Low & High \\
\hline $\mathbf{S}$ & & High & High & High & Low \\
\hline $\mathbf{T}$ & & High & High & High & High \\
\hline
\end{tabular}

(C.F) The collected samples were purified and multiplied on the susceptible cv (Morocco and Triticum spelta saharense ) and identified on the stem rust on wheat differentials at seedling stage.

Table (2): Wheat stem rust infection types used in disease assessment for seedling stage.

\begin{tabular}{|c|c|c|}
\hline Host response (class) & Infection types & Disease symptoms \\
\hline Immune & 0 & $\begin{array}{l}\text { No uredia or other macroscopic sign of } \\
\text { infection. }\end{array}$ \\
\hline Nearly immune & O; & $\begin{array}{l}\text { No, uredia but hypersensitive necrotic or } \\
\text { chlorotic flecks present. }\end{array}$ \\
\hline Very resistant & 1 & Small uredia surrounded by necrosis. \\
\hline Moderate resistant & 2 & $\begin{array}{l}\text { Small to medium uredia surrounded by } \\
\text { chlorosis or necrosis. }\end{array}$ \\
\hline Moderate susceptible & 3 & $\begin{array}{l}\text { Medium-sized uredia that may be associated } \\
\text { with chlorosis. }\end{array}$ \\
\hline Very susceptible & 4 & $\begin{array}{c}\text { Large uredinia without chlorosis or necrosis } \\
\text { or rarely necrosis. }\end{array}$ \\
\hline Heterogeneous & $\mathrm{X}$ & Random distribution of $v$ \\
\hline
\end{tabular}

\section{RESULTS}

\section{Frequency of Virulence:}

Frequency of virulence of the causal organism Puccinia garminis of wheat stem rust was studied using rust samples collected from lower Egypt during 2008/09-2009/010. The obtained cultures were tested in the following seasons 2008/09-2009/010. Virulence was tested against 35 monogenic lines for stem rust resistance Occurrence of virulence was estimated as virulent isolates a divided by the total number of isolates for each wheat genotype. 
Faizallah, E.A. et al.

Frequency of virulence to Srs genes:

1) Occurrence of virulence in 2008/09:

The results presented in Table (3), showed different frequencies of virulence to the tested lines. The lowest values were found against $\mathrm{Sr} 31, \mathrm{Sr}$ $6 \mathrm{Sr}$ PLand Sr WLD ranging from $0 \%$ to $17.39 \%$ in an ascending order. On the other hand, the highest occurrence of virulence was found against $\mathrm{Sr}$ $21+9 \mathrm{~g}, \mathrm{Sr} 7 \mathrm{a}$ and $\mathrm{Sr} 29$ ranging 69.57 to 89.13 in a descending order . whereas, the rest of lines showed moderate responses, as shown in Table (3).

Table (3): Frequency of virulence of Puccinia graminis tritici to 36 monogenic lines for stem rust resistance at 2008/09*.

\begin{tabular}{|c|c|c|c|c|c|c|}
\hline No. & Sr's & $\begin{array}{c}\text { Avir. } \\
\text { isolates }\end{array}$ & Vir. isolates & Total & $\begin{array}{c}\text { Effective } \\
\text { gene }\end{array}$ & $\begin{array}{c}\text { Vir. } \\
\text { frequency }\end{array}$ \\
\hline 1 & Sr5 & 33 & 13 & 46 & 71.74 & 28.26 \\
\hline 2 & Sr6 & 39 & 7 & 46 & 84.78 & 15.22 \\
\hline 3 & Sr7a & 6 & 40 & 46 & 13.04 & 86.96 \\
\hline 4 & $S r 7 b$ & 23 & 23 & 46 & 50.00 & 50.00 \\
\hline 5 & Sr8a & 28 & 18 & 46 & 60.87 & 39.13 \\
\hline 6 & Sr8b & 36 & 10 & 46 & 78.26 & 21.74 \\
\hline 7 & Sr9a & 18 & 28 & 46 & 39.13 & 60.87 \\
\hline 8 & Sr9b & 30 & 16 & 46 & 65.22 & 34.78 \\
\hline 9 & Sr9d & 22 & 24 & 46 & 47.83 & 52.17 \\
\hline 10 & Sr9e & 31 & 15 & 46 & 67.39 & 32.61 \\
\hline 11 & Sr9g & 37 & 9 & 46 & 80.43 & 19.57 \\
\hline 12 & Sr10 & 22 & 24 & 46 & 47.83 & 52.17 \\
\hline 13 & Sr11 & 21 & 25 & 46 & 45.65 & 54.35 \\
\hline 14 & Sr13 & 29 & 17 & 46 & 63.04 & 36.96 \\
\hline 15 & Sr15 & 31 & 15 & 46 & 67.39 & 32.61 \\
\hline 16 & Sr16 & 13 & 33 & 46 & 28.26 & 71.74 \\
\hline 17 & Sr17 & 33 & 13 & 46 & 71.74 & 28.26 \\
\hline 18 & Sr21 & 30 & 16 & 46 & 65.22 & 34.78 \\
\hline 19 & Sr22 & 17 & 29 & 46 & 36.96 & 63.04 \\
\hline 20 & Sr23 & 31 & 15 & 46 & 67.39 & 32.61 \\
\hline 21 & Sr24 & 23 & 13 & 36 & 63.89 & 36.11 \\
\hline 22 & Sr28 & 10 & 19 & 29 & 34.48 & 65.52 \\
\hline 23 & Sr29 & 14 & 32 & 46 & 30.43 & 69.57 \\
\hline 24 & Sr30 & 26 & 20 & 46 & 56.52 & 43.48 \\
\hline 25 & Sr31 & 35 & 1 & 36 & 97.22 & 2.78 \\
\hline 26 & Sr32 & 16 & 30 & 46 & 34.78 & 65.22 \\
\hline 27 & Sr33+Sr5 & 33 & 13 & 46 & 71.74 & 28.26 \\
\hline 28 & Sr34 & 14 & 32 & 46 & 30.43 & 69.57 \\
\hline 29 & Sr35 & 14 & 32 & 46 & 30.43 & 69.57 \\
\hline 30 & Sr36 & 34 & 12 & 46 & 73.91 & 26.09 \\
\hline 31 & SrPL & 40 & 6 & 46 & 86.96 & 13.04 \\
\hline 32 & SrWLD & 38 & 8 & 46 & 82.61 & 17.39 \\
\hline 33 & SrTT3+Sr10 & 31 & 15 & 46 & 67.39 & 32.61 \\
\hline 34 & SrDP2 & 19 & 11 & 30 & 63.33 & 36.67 \\
\hline 35 & SrTMP & 25 & 21 & 46 & 54.35 & 45.65 \\
\hline 36 & Sr21+9g & 5 & 41 & 46 & 10.87 & 89.13 \\
\hline
\end{tabular}


2)Occurrence of virulence in 2009/010:

Obtained results revealed that the lowest frequencies of virulence were found against $\operatorname{Sr} W L D, \operatorname{Sr} 30, \operatorname{Sr} 6$ and Sr9g. On the other hand $\operatorname{Sr} 6$, $\mathrm{Sr} 9 \mathrm{e}, \mathrm{Sr} 17$ and $\mathrm{Sr} 9 \mathrm{a}$ averse arranged according to their virulence frequency $88.04,83.87,82.97$ and 80.85 respectively .

Table (4): Frequency of virulence of Puccinia graminis tritici to 36 monogenic lines for stem rust resistance at 2009/010.

\begin{tabular}{|c|l|c|c|c|c|c|}
\hline No. & Sr's & $\begin{array}{c}\text { Avir. } \\
\text { isolates }\end{array}$ & $\begin{array}{c}\text { Vir. } \\
\text { isolates }\end{array}$ & Total & $\begin{array}{c}\text { Effective } \\
\text { gene }\end{array}$ & $\begin{array}{c}\text { Vir. } \\
\text { frequency }\end{array}$ \\
\hline 1 & Sr5 & 27 & 67 & 92 & 28.87 & 71.27 \\
\hline 2 & Sr6 & 11 & 81 & 92 & 11.95 & 88.04 \\
\hline 3 & Sr7a & 30 & 66 & 96 & 31.25 & 68.75 \\
\hline 4 & Sr7b & 28 & 64 & 92 & 30.43 & 69.56 \\
\hline 5 & Sr8a & 31 & 70 & 91 & 34.06 & 76.92 \\
\hline 6 & Sr8b & 21 & 75 & 96 & 21.87 & 78.12 \\
\hline 7 & Sr9a & 18 & 76 & 94 & 19.14 & 80.85 \\
\hline 8 & Sr9b & 21 & 75 & 96 & 21.87 & 78.12 \\
\hline 9 & Sr9d & 33 & 61 & 94 & 35.10 & 64.89 \\
\hline 10 & Sr9e & 15 & 78 & 93 & 16.12 & 83.87 \\
\hline 11 & Sr9g & 19 & 79 & 98 & 19.38 & 80.61 \\
\hline 12 & Sr10 & 33 & 63 & 96 & 34.37 & 65.62 \\
\hline 13 & Sr11 & 32 & 58 & 90 & 35.55 & 64.44 \\
\hline 14 & Sr13 & 33 & 67 & 100 & 33.00 & 67.00 \\
\hline 15 & Sr15 & 27 & 71 & 98 & 27.55 & 72.44 \\
\hline 16 & Sr16 & 67 & 28 & 95 & 70.52 & 29.47 \\
\hline 17 & Sr17 & 16 & 78 & 94 & 17.02 & 82.97 \\
\hline 18 & Sr21 & 26 & 61 & 95 & 27.36 & 64.21 \\
\hline 19 & Sr22 & 40 & 51 & 91 & 43.95 & 56.04 \\
\hline 20 & Sr23 & 30 & 61 & 91 & 32.96 & 67.03 \\
\hline 21 & Sr24 & 39 & 52 & 91 & 42.85 & 57.14 \\
\hline 22 & Sr28 & 35 & 56 & 91 & 38.46 & 61.53 \\
\hline 23 & Sr29 & 82 & 18 & 100 & 82.00 & 18.00 \\
\hline 24 & Sr30 & 12 & 83 & 95 & 12.63 & 87.36 \\
\hline 25 & Sr31 & 84 & 7 & 93 & 90.32 & 7.52 \\
\hline 26 & Sr32 & 55 & 35 & 90 & 61.11 & 38.88 \\
\hline 27 & Sr33+Sr5 & 66 & 24 & 90 & 73.33 & 26.66 \\
\hline 28 & Sr34 & 47 & 43 & 90 & 52.22 & 47.77 \\
\hline 29 & Sr35 & 70 & 18 & 98 & 71.42 & 18.36 \\
\hline 30 & Sr36 & 4 & 90 & 94 & 4.25 & 95.74 \\
\hline 31 & SrPL & 25 & 62 & 87 & 28.73 & 71.26 \\
\hline 32 & SrWLD & 25 & 70 & 95 & 26.31 & 73.68 \\
\hline 33 & SrTT3+Sr10 & 28 & 64 & 92 & 30.43 & 69.56 \\
\hline 34 & SrTMP & 47 & 49 & 96 & 48.95 & 51.04 \\
\hline 35 & Sr21+9g & 74 & 17 & 91 & 81.31 & 18.68 \\
\hline & & & & & & \\
\hline
\end{tabular}


Faizallah, E.A. et al.

Physiologic races identification:

a. The first season 2008/09:

Table (5): revealed the occurrence of 44 race group of stem rust (Puccinia garminis f. sp tritici West.). These race groups were i.e.

\begin{tabular}{|c|c|c|c|c|c|c|c|}
\hline No. & $\begin{array}{c}\text { Race } \\
\text { group }\end{array}$ & $\begin{array}{c}\text { No. of } \\
\text { Isolates }\end{array}$ & $\begin{array}{c}\text { Frequency } \\
(\%)\end{array}$ & No. & $\begin{array}{c}\text { Race } \\
\text { group }\end{array}$ & $\begin{array}{c}\text { No. of } \\
\text { Isolates }\end{array}$ & $\begin{array}{c}\text { Frequency } \\
(\%)\end{array}$ \\
\hline 1 & TK- & 5 & 8.33 & 23 & MS- & 1 & 1.66 \\
\hline 2 & TR- & 4 & 6.66 & 24 & MT- & 1 & 1.66 \\
\hline 3 & TT- & 4 & 6.66 & 25 & NC- & 1 & 1.66 \\
\hline 4 & LC- & 3 & 5.00 & 26 & PG- & 1 & 1.66 \\
\hline 5 & ST- & 3 & 5.00 & 27 & PF- & 1 & 1.66 \\
\hline 6 & BH- & 2 & 3.33 & 28 & PK- & 1 & 1.66 \\
\hline 7 & QG- & 2 & 3.33 & 29 & PT- & 1 & 1.66 \\
\hline 8 & BB- & 1 & 1.66 & 30 & QC- & 1 & 1.66 \\
\hline 9 & BF- & 1 & 1.66 & 31 & QF- & 1 & 1.66 \\
\hline 10 & BL- & 1 & 1.66 & 32 & QK- & 1 & 1.66 \\
\hline 11 & BT- & 1 & 1.66 & 33 & QS- & 1 & 1.66 \\
\hline 12 & BK- & 1 & 1.66 & 34 & QT- & 1 & 1.66 \\
\hline 13 & CK- & 1 & 1.66 & 35 & NH- & 1 & 1.66 \\
\hline 14 & DJ- & 1 & 1.66 & 36 & RK- & 1 & 1.66 \\
\hline 15 & DK- & 1 & 1.66 & 37 & RR- & 1 & 1.66 \\
\hline 16 & FT- & 1 & 1.66 & 38 & SC- & 1 & 1.66 \\
\hline 17 & JH- & 1 & 1.66 & 39 & SL- & 1 & 1.66 \\
\hline 18 & JK- & 1 & 1.66 & 40 & SJ- & 1 & 1.66 \\
\hline 19 & JR- & 1 & 1.66 & 41 & SK- & 1 & 1.66 \\
\hline 20 & HR- & 1 & 1.66 & 42 & SR- & 1 & 1.66 \\
\hline 21 & KT- & 1 & 1.66 & 43 & TS- & 1 & 1.66 \\
\hline 22 & MQ- & 1 & 1.66 & 44 & TH- & 1 & 1.66 \\
\hline
\end{tabular}

TK, TR, TT, LC, ST, BH, QG, BB, BF, BL, BT, BK, CK, DJ, DK, FT, JH, JK, JR,HR, KT, MQ, MS, NC, PG,PF, PK, PT, QC, QF, QK, QS, QT, NH, RK, RR, SC, SL, SJ, SK, SR, TS and TH were determined on the basis of sum of high infection types for each of 20 wheat stem rust monogenic differentials.

The surveyed samples of the 2008/09 in Northern governorates of Egypt. These data revealed that race group TK was the most frequent one (8.33\%) followed by race group TR- and TT which were more frequent (6.66 $\%)$ followed by race group LC- and ST (5.00\%), by race group BH- and QG$(3.33 \%)$ - least ones in this regard were race groups i.e. BB, BF, BL,BT, BK and $\mathrm{CK}(1.66 \%)$. the rest of races recorded less than 1.66 
b. The second season 2009/010:

Table (6): Physiologic races of Puccinia graminis f. sp. tritici and their frequency (\%) in Egypt during 2009/010.

\begin{tabular}{|c|c|c|c|c|c|c|c|}
\hline No. & $\begin{array}{c}\text { Race } \\
\text { group }\end{array}$ & $\begin{array}{c}\text { No. of } \\
\text { Isolates }\end{array}$ & $\begin{array}{c}\text { Frequency } \\
(\%)\end{array}$ & No. & $\begin{array}{c}\text { Race } \\
\text { group }\end{array}$ & $\begin{array}{c}\text { No. of } \\
\text { Isolates }\end{array}$ & $\begin{array}{c}\text { Frequency } \\
\text { (\%) }\end{array}$ \\
\hline 1 & TT- & 17 & $16-66$ & 25 & GH- & 1 & 0.98 \\
\hline 2 & TS- & 12 & $11-76$ & 26 & KJ- & 1 & 0.98 \\
\hline 3 & KT- & 6 & $5-88$ & 27 & KF- & 1 & 0.98 \\
\hline 4 & TK- & 6 & 5.88 & 28 & CQ- & 1 & 0.98 \\
\hline 5 & BB- & 3 & 2.94 & 29 & FT- & 1 & 0.98 \\
\hline 6 & DH- & 3 & 2.94 & 30 & NR- & 1 & 0.98 \\
\hline 7 & LC- & 3 & 2.94 & 31 & NT- & 1 & 0.98 \\
\hline 8 & PR- & 3 & 2.94 & 32 & NS- & 1 & 0.98 \\
\hline 9 & SR- & 3 & 2.94 & 33 & PT- & 1 & 0.98 \\
\hline 10 & BL- & 2 & 1.96 & 34 & PJ- & 1 & 0.98 \\
\hline 11 & JT- & 2 & 1.96 & 35 & LT- & 1 & 0.98 \\
\hline 12 & KG- & 2 & 1.96 & 36 & LK- & 1 & 0.98 \\
\hline 13 & KK- & 2 & 1.96 & 37 & RK- & 1 & 0.98 \\
\hline 14 & TP- & 2 & 1.96 & 38 & HR- & 1 & 0.98 \\
\hline 15 & TR- & 2 & 1.96 & 39 & QR- & 1 & 0.98 \\
\hline 16 & ST- & 2 & 1.96 & 40 & SM- & 1 & 0.98 \\
\hline 17 & BC- & 1 & 0.98 & 41 & SG- & 1 & 0.98 \\
\hline 18 & BH- & 1 & 0.98 & 42 & SH- & 2 & 1.96 \\
\hline 19 & BK- & 1 & 0.98 & 43 & SK- & 1 & 0.98 \\
\hline 20 & DG- & 1 & 0.98 & 44 & TP- & 1 & 0.98 \\
\hline 21 & DF- & 1 & 0.98 & 45 & TQ- & 1 & 0.98 \\
\hline 22 & DT- & 1 & 0.98 & 46 & TH- & 1 & 0.98 \\
\hline 23 & BS- & 1 & 0.98 & 47 & TB- & 1 & 0.98 \\
\hline 24 & FH- & 1 & 0.98 & & & & \\
\hline 7 & KT & BB- & DH, PR, & & & 1 & 1 \\
\hline
\end{tabular}

TT, TS, KT, BB, LC, DH, PR, SR, BL, JT, KG, KK, TP, TR, ST, BC, BH, BK, DG, DF, DT, BS, FH, GH, KJ,KF, CQ, FT, NR, NT, NS, PT, PJ, LT, RK, HR, QR, SM, SG, SH, SK, TP, TQ, TH and TB were determined on the basis of sum of high infection types for each of 20 wheat stem rust monogenic differentials.

The survey samples of the 2008/09 in Northern governorates of Egypt. These data revealed that race group TT was the most frequent one (16.66\%) followed by race group TT- was most frequent $(16.16 \%)$ followed by race group TS- $(11.76 \%)$ followed by race group KT- and TK- ( $5.88 \%)$ followed by race group BB-, DH, PR, and SR (2.94\%).. The least ones in the regard were races group $\mathrm{BC}, \mathrm{BH}, \mathrm{BK}, \mathrm{DG}, \mathrm{DF}$ and $\mathrm{DT}(0.98 \%)$.

\section{DISCUSSION}

Stem rust of wheat (Triticum aestivum L.) caused by Puccinia garminis tritici is considered one of the most serious diseases in Egypt. The disease became a very dangerous on most of the currently introduced varieties because of their susceptibility to the disease (El-Daoudi, et al., 1996 ). It usually occurs at higher level of severity on the late sowings than in 
Faizallah, E.A. et al.

early ones when the environmental conditions became suitable for rust incidence and development (Bariana HS, Brown GN, Bansal UK, Miah H, Standen GE, Lui M, 2007).

Stem rust can be considered as a sporadic disease because it appears in some seasons but not in the others. It appeared in epidemic cases in 1947 and 1968 (Gomma 1968). Moreover, all wheat genotypes produced in Egypt were susceptible in terms of infection types. Therefore, to protect the local genotypes from infection by such disease, genes for resistance must be incorporated into the high yielding genotypes.

The annual survey of Wheat stem rust conducted through out two growing seasons of wheat crop in some governorates of Egypt gave evidence to the presence of different virulence of the causal agent(Puccinia garminis tritici West .). The obtained results were established on the comparisons of both visual symptoms as infection types of the uredial stage of the casual agent with those reported by Wiese (1977) and Agrios ((1979).

Isolation and identification of the prevailing races of the disease are an essential step to satisfy this work(AbuEl-Naga et al.,(1993). In the course of this study, virulence survey was carried out by collecting stem rust samples from different locations of Egypt.

The obtained results in seedling stage gave evidence to presence of 44 and 47 race groups of stem rust during the two successive seasons 2008/09 and 2009/010, respectively.

In general rust causal organisms are air- borne pathogens which are carried by wind from their source to the susceptible plants (Chen et al., 2005). Therefore, the inoculate play an important role in the occurrence and frequency of virulence (AbuEl-Naga et al.,(1990)

The appearance of new virulence is due to the appearance of new mutation, hetrokaryosis and the hybridization of genetically different individuals (Stakman 1962).

Virulence occurrence against the different stem rust genes also was of different values depending on the host - race compatibility (Beteselassie, N., C. Fininsa \& A. Badebo. 2007)

In the present, The least frequencies of virulence were recorded with Sr 31, SrPL, Sr6, SrWLD, Sr9g, Sr8b, Sr5 and Sr17 showing 2.78. 13.04, $15.22,17.39,19.57,21.74,28.28$ and 28.28 frequencies, respectively. On the cother hand, Sr21+9g, Sr7a and Sr16 showed highest frequencies of virulence $(89.13,96.96$ and 71.74), respectively. While the rest of $\mathrm{Sr}$ genes showed different frequencies of virulence from 28.28 to 71.74 during first season.

Frequencies of virulence occurrence with the tested $\mathrm{Sr}$ genes in terms of infection types showed vourialele responses. The least frequencies of virulence were recorded with $\mathrm{Sr} 31, \mathrm{Sr} 29, \mathrm{Sr} 35, \mathrm{Sr} 21+9 \mathrm{~g}, 33+\mathrm{Sr} 5 \mathrm{Sr} 16$ and Sr32 showing 7.52, 18.00, 18.36, 18.68, 26.66, 29.47 and 38.88 frequencies, respectively. On the other hand, Sr6, Sr9e and Sr9a showed the highest frequencies of virulence ( $88.04,83.87$ and $80.85 \%$ ), respectively. The rest of $\mathrm{Sr}$ genes showed different frequencies of virulence ranged from 38.88 to 80.85 Chen T.et al. (1997) Sawhncy (1998), Pretorius et. al. (2000) and Hassain (2006) 


\section{REFERENCEES}

A bu El-Naga, S.A.; I. Shafik; Y.H. El-Daoudi and S. Sherif (1990). Virulence of Puccinia graminis tritici and genes conferring resistance in wheat $6^{\text {th }}$ Congr. Phytopath. Cairo March. 1990, 99-109.

Abu El-Naga, S.A.; M.M. Kalifa; A.M. Ommar; M.A. Nagib and A.M. Saleh (1993). Effect of stem rust inocula obtained from different wheat genotypes on race identify and virulence trends of Puccinia graminis tritici in Egypt during 1990/91. J. Agric. Sci. Mans. Univ. 18(10): 2960-2968.

Agrios, G.N. (1979). Plant Pathology, Academic Press, New York pp.703.

Bariana HS, Brown GN, Bansal UK, Miah H, Standen GE, Lui M, 2007. Breeding triple rust resistant wheat cultivars for Australia using conventional and marker-assisted selection technologies. Australian Journal of Agricultural Research 58: 576-87

Beteselassie, N., C. Fininsa \& A. Badebo. 2007. Sources of resistance to stem rust (Puccinia graminis f. $\mathrm{sp}$. triticl) in Ethiopian tetraploid wheat accessions. Genet. Resources Crop Evol. 54: 337-343.

Bolate, N. and A.P. Roelfs (1991). Resistance of durum wheals used as differential hosts for stem rust. Plant Dis. 75(6): 563-568.

Chen, WanQuan; Qin QingMing; Wang KuiRong; Xia ShanBao; Feng GuoHua;Chen RongZheng; W.Q. Chen; q.m Qin; K.R. Wang; S.B. Xia; G.H. Feng and R.Z. Chen (1997). Genes for leaf and stem rust resistance in important wheat cultivars in Jiangsu Province Acta Pytophylacica Sinica 24(3):225-234.

El-Daoudi, Y.H.; M. Nazim; A.A. Agee; I. Shafik and S.A. Abu El-Naga (1990). Yield reduction in seven Egyptian wheat cultivars caused by stem rust infection. Rachis 9(1): 14-17.

El-Daoudi, Y.H.; O.F. Mamluk; S.A. Abu El-Naga; M.S. Ahmed; E. Bekele; N. El-Sherif and M.M.O. Kalifa (1996). Virulence survey of Puccinia graminis tritici and genes conferring resistance to wheat stem rust in the Nile Valley Countries, Yemen and Syria during 1992/1993 and 1993/1994. Egypt. J. Appl. Sci. 11(3).

Gomma, A. S. A. (1968) Report of the Egyptian wheat varieties and their development Egyptin Soc. Of Genetics Science, Cairo.

Hassan, M. A. (2006). Performance of the Egyptian wheat varieties to stem rust and dynamic of virulence of the causal organism. Ph.D. Thesis, University of Minufiya, Egypt.

Pretorius, Z. A; R. P. Singh and W. W. Wagoire (2000) Detection of virulence to wheat stem rust resistance gene $\mathrm{Sr} 31$ in Puccinia graminis F. Sp tritici in Uganda.Plant Disease, 84: 203;1lef; E. E

Roelfs, A.P.; D.H. Casper; D.L. Long and J.J Roberts (1987). Races of puccinia graminis in the Uinted States and Mexico during 1986. Plant Disease 71(10):903-910. 
Faizallah, E.A. et al.

Roelfs, A.P. and J.W. Martens (1988). An international system of nomenclature for Puccinia graminis f. sp. tritici. Phytopath. 78(5): 526-533.

Roelfs, A.P.; D.L. Long and J.J. Roberts (1993). Races of Puccinia graminis in United States during 1990. Plant Dis. 77(2): 125128.

Sawhney, R.N. (1998). Genetic analysis of wheat rust interactions and strategies to breed for durable resistance. Indian J. Genet. Plant Breeding. 58(4): 391-416.

Simons, M.D.; J.W. Martens; R.I.H. McKenzie; I. Nishiyama; K. sadanaga; J. Sebesta and H. Thomas (1978). Oats: A standardized system of nomenclature for genes and chromosomes and catalogue of genes governing characters U.S., Dept. Agric., Handbook. 509, 1-40.

Stakman, E.C. Sewart D.M. and Loegering W.Q.(1962) Identification of physiologic races of Puccinia graminis tritici ARS, USDA, Agr. Res. Serv.Bull.E-617. $53 \mathrm{pp}$

Wiese, M.V. 1977. Compindium of wheat diseases. Incorporation with Dept. Bot. And Plant Pathol., Michigan State Univ. of Nebraska, Lincoln. pp 106.

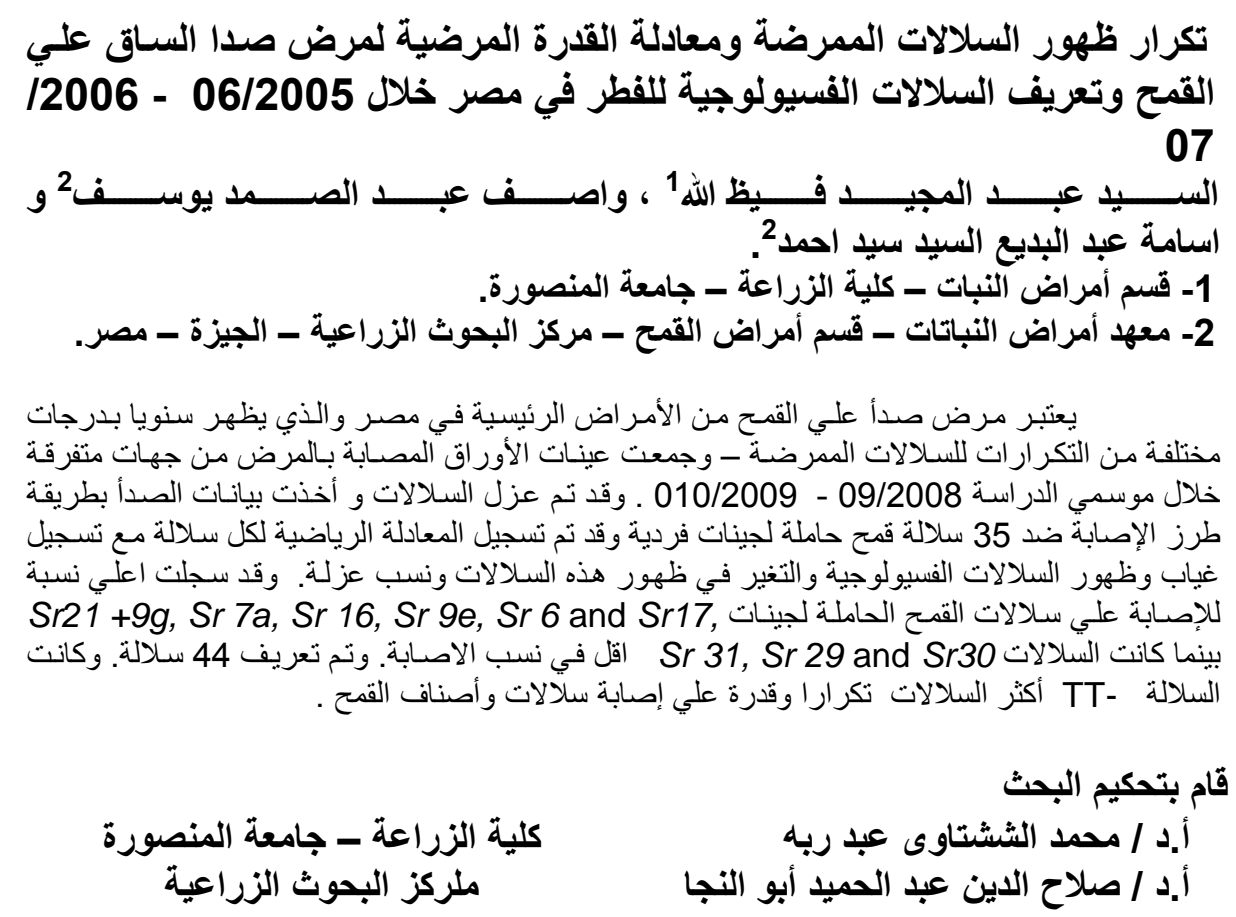

